\title{
The Forgetting of the Penetrable Body: Simone de Beauvoir, Silence, Omission in Jacques Derrida
}

\author{
O Esquecimento do corpo penetrável: Simone de Beauvoir, Silêncio, \\ Omissão em Jacques Derrida
}

Norman Roland Madarasz ${ }^{1}$

\begin{abstract}
Jacques Derrida is known for his attempt at including the perspective of woman in his philosophical work. His efforts received the acclaim of women philosophers, despite the fact that his philosophy remains marked by the omission of any mention to the work of Simone de Beauvoir. The topic of this paper shall not be woman, as in Derrida's 1972 conference Spurs, but phallogocentrism. That is, the economy, dynamic and limits of this concept as a critique of history, or rather, as the history of the lie, the term by which Derrida seems to conceive of the possibility of any (political) history whatsoever. We agree that phallogocentrism in Derrida's hands enabled anti-philosophical forays by which to include woman as singularity in the maledominated French philosophy of the 1970s. However, we also argue that the specter of man was maintained untouched throughout Derrida's work, thereby suggestion that deconstruction overlooked what may very well be the primary prohibition in Western thought. Keywords: Phallogocentrism; woman; history; anti-philosophy; heteronormative male body; error; lie.
\end{abstract}

Resumo: Jacques Derrida é conhecido por suas tentativas a incluir a perspectiva da mulher no seu trabalho filosófico. Seus esforços receberam o elogio de filósofas, apesar do fato de sua filosofia permanecer marcada pela omissão de qualquer menção ao trabalho de Simone de Beauvoir. O assunto deste artigo não será a mulher, como na conferência de 1972 Esporas, mas o falogocentrismo. Ou seja, a economia, dinâmica e os limites deste conceito enquanto crítica da história, isto é, a história da mentira, termo pelo qual Derrida parece conceber da possibilidade de qualquer história (política). Concorda-se que o falogocentrismo, nos cuidados de Derrida, proporcionou as saídas antifilosóficas pelas quais incluir a mulher como singularidade na filosofia francesa dos anos de 1970 dominada por homens. No entanto, defenderemos que o espectro do homem foi mantido intato por Derrida no seu trabalho, o que sugere que a desconstrução tem ignorado aquilo que poderia bem ser a proibição primária no pensamento ocidental.

Palavras-chave: Falogocentrismo; mulher; história; antifilosofia; corpo heteronormativo do homem; erro; mentira. 
Jacques Derrida loved women. This is perhaps a subjective impression, although one that is not wrong. An apostle of incompleteness, Derrida loved women intellectually and, from what can be understood from his biographers, he loved them sexually (Powell, 2006; Peeters, 2010). Indeed, he may have loved them to the point of totalizing them. Totalizing, since for a male philosopher, to be a lover of women is only a banal assessment of heteronormative hegemony in the post-monogamic state of the profession. A pure description of improper existence that reinforces facticity. But when one becomes a man by linking up professionally with women, one deals with a relationship that mixes with other substances, thus plausibly triggering performativity. Jacques Derrida loved women. And by the looks of it, women loved Jacques Derrida. The statements and recognition expressed by female scholars of different nationalities of Derrida's work are surprising by the consensus in which they have been manifested. Elizabeth Grosz, professor of philosophy and queer studies at Rutgers University, writes: "With the exception of John Stuart Mill, I would suggest that Derrida is really the first (male) philosopher for whom feminism is essential if philosophy is to be undertaken properly, adequately, or well.”2 Carole Dely, former editor of Sens Public, musician and scholar at the George Pompidou Center in Paris, notes, albeit in messianic hues:

by not, or no longer, excluding her, but on the contrary inviting her to come, take back a place, her place, the one the tradition perhaps had refused her while developing itself into that particular tradition (the one that will have validated the phallocentric model, the figure of the man, the brother, without valuing the sister if not reducing her to a brother, and so forth), it would have been necessary for the "philosopher" - the man in a sense representative of this tradition, affiliated with it while at the same time setting himself apart from it - to invite the woman herself to speak, of herself. That is what Jacques Derrida will have done through deconstruction. ${ }^{3}$

\footnotetext{
${ }^{2}$ GROSZ, E., "Derrida and Feminism: A Remembrance", in d iffe r e $n$ c e s : A Journal of Feminist Cultural Studies, $16: 3,2005$, p. 88.

3 DELY, Carole, "Jacques Derrida: The Perchance of a Coming of the Otherwoman. (The Deconstruction of 'Phallogocentrism' from Duel to Duo). Sens public. Published on line: 2007/10. < http://www.senspublic.org/article.php3?id article=312>, p. 14 .
} 
Writer and philosopher, Hélène Cixous, also Franco-Algerian and with whom Derrida co-authored Veils (1998), termed him a "young Jewish saint". ${ }^{4}$ The list may be extended to other sources of acclaim coming from Brazilian and French female scholars alike. Carla Rodrigues from the Federal University of Rio de Janeiro (2010), or Catherine Malabou, from Kingston University, London :"I never met anyone whom I admired as much after [Derrida] and never will"5, as well as historian of psychoanalysis, Elizabeth Roudinesco (2005), or the feminist philosopher, Sylviane Agacinski.

The commemoration of Derrida's work by women and feminist philosophers is largely warranted by the concept of phallocentrism, put forward at first in Margins ${ }^{6}$, and thereafter carved into a weapon in Spurs: Nietzsche's Styles. ${ }^{7}$ In this paper, I should like to move up close to this concept, since it has not been intensively worked on in the way it perhaps ought to, namely through a prism of multiple perspectives, deconstructively to be sure, but also critically and dialectically as well as through a symptomatic reading of current and past scholarship on Derrida. Phallocentrism and its compounded variation as "phallo-logophono-centrism" certainly point to a limit in philosophy. At the same time, I should like to put forward a small claim according to which were we not to leave from this limit, and explore the antiphilosophical dimension implicated by this concept and characteristic of Derrida's work of the 1970s, phallogocentrism operates mainly to erase the question of history. That is, as much as antiphilosophy fosters critical openings on the philosophical enterprise and its constituting of a space for discursive practices, it is no more sensitive to the problems of history than is philosophy per se. Philosophy generally professes history to be partial and belonging to the domain of opinion. In philosophical vernacular, this

\footnotetext{
${ }^{4}$ CIXOUS, H. Portrait de Jacques Derrida en jeune saint juif. Paris: Éditions Galilée, 2004

${ }^{5}$ Malabou made this statement during the question period of her talk "Post-Gender Theory and the Feminine", at the May 2014 7th Subversive Festival: "Power and Freedom in the time of Control" in Zagreb, Croatia. For the full extent of Derrida's importance on her formative period as a philosopher ("I would say that I wasn't a philosopher before I met him. I used to be just a student in philosophy and things really started when I met him. "), cf. Vahanian, 2008, p. 2. For "Post-Gender Theory and the Feminine", the video reference is the following: <https://www.youtube.com/watch?v=oMOlisKRO5M>.

${ }^{6}$ DERRIDA, J. Marges. De la philosophie. Paris: Éditions du Minuit, 1972.1972, p.xviii.

${ }^{7}$ DERRIDA, J. Spurs: Nietzsche's Styles. Éperons. Les Styles de Nietzsche. Introduction by Stefano Agosti. English Translation by Barbara Harlow. Drawings by François Loubrieu. Chicago, Ill.: The University of Chicago Press, 1979 [1978], p. 61 .
} 
means the field of error. Antiphilosophy is merely the guardian of this secret.

It will thus be from the configuration of the secret, whose aporetic force Derrida more than others insisted on recognizing, but which does not cease to trigger a vulgar and improper sense of curiosity, once explored in the existential analytic by Heidegger, that I should like to take on Derrida's theory of history. Given the record of acceptance by so many women of the avant-garde nature of his work in the 1970s - namely, on how this work approaches by means of phallo-logo-phono-centrism the forays from philosophy experimented by French thinkers and writers, such as Luce Irigaray, Julia Kristeva and Hélène Cixous, and considering that Brazil is currently in the throes of a moment of increasing contributions by female philosophers and scholars on the conditions of gender and racial inequality by which philosophy within its national universities seems doomed to perpetuate itself - we shall leave off from a point of curiosity, which also works as our observational hypothesis: Derrida never commented on the work of the two major women of French philosophy and literature of the twentieth century, that is, Simone de Beauvoir and Marguerite Duras.

Faced with these omissions, which are not merely accidental or secondary, I do not seek a trial. What I shall do is only to give space to a curiosity of a historical order. Given that Derrida suspected political history of mainly perpetuating errors and lies, I find myself faced with a dilemma. That he suspected history is not surprising, since, like Foucault, Deleuze and Guattari and others, Derrida sought to break with the traditional intellectual history exalting masters, sovereigns and authors. The first amongst other monumental fights he waged was focused on the history of madness, that is, the history of the "absence of work" undertaken by Foucault. Regarding himself, Derrida, like Maurice Blanchot, but also like Marguerite Duras, famously wrote and rewrote his own history based on phantasms, simulacra and dissimulation. It is necessary to recall that the thinker of hospitality went through deconstructive phases the aims of which were without a doubt destructive. Whether this phase is commemorated or not means little to me, even though it did aim at humanism and its logocentrist legacy. What is important, though, and this should not be omitted, is that during that time 
that Derrida was structuralist - another theoretical debt on which philosophical tradition has defaulted.

The omission of Simone de Beauvoir and Marguerite Duras in Derrida's considerations on woman, writing, sexual difference and performative transcendence avant la lettre is another matter, literally the matter of an other. Curiosity leads us then to examine the evocation made in a passage of the film produced in 2002, Jacques Derrida, by Kirby Dick and Amy Ziering (Zeitgeist Films) in which Derrida unequivocally asserts in English: "It is impossible for me to have any philosopher as my mother." After an attempt at continuing this thought in English, he reverts to French and categorically asserts for a second time: "deconstruction of phallogocentrism as a whole is deconstruction of what is called philosophy inasmuch as it has always been linked to the paternal and male figure." The passage comes to a conclusion with Derrida explaining in an inversion of filiation evocative of La Carte Postale, that, as such, he cannot have a "philosopher mother", but only a "grandson". Or, insofar as thought and philosophy are distinct, he seeks to "give birth" (faire naitre) to a "thinking granddaughter" who "evidently" will be "post-deconstructionist”.

If my understanding is not off the mark, it is the deconstruction of phallogocentrism that prevents Derrida from recognizing he is heir to any female philosopher. To follow his rationale on differential temporality, there would not have been any women philosophers prior to his spectral existence, although thinking women certainly existed. Although we follow Derrida's deconstruction of philosophical temporality, the rebound effect on representing female absence in the institutionalized framework of philosophical studies puts us in a tight, uncomfortable corner.

The topic, then, of this paper shall not be woman, as in Spurs, but phallogocentrism. That is, the economy, dynamic and limits of this concept as the instance of history, or rather, of the history of the lie as conceived as "radical evil", thereby linking it to the way Derrida seems to conceive of the possibility of any political history whatsoever. (Derrida, 2002, p 70). Asserting that there have been no women philosophers would be to qualify history. But would it not be precisely the qualification of this history as the history of a lie which would thus free the lie from its opposition to truth?

8Jacques Derrida. Zeitgeistfilms, 2002. "Toute la déconstruction du phallogocentrisme, c'est la déconstruction de ce qu'on appelle la philosophie en tant qu'elle a été lié depuis toujours à une figure paternelle et masculine. La philosophie est un père, elle n'est pas une mère. “ 
Simone de Beauvoir herself certainly articulated a history of the lie. Indeed, in the Second Sex, she structured the lie in the shape of great art, great thought as well as great philosophy. Marguerite Duras also made the lie not merely the mark of her life, but its seal, practicing the art of writing as an emancipation from history, given that history can only be lying if fiction were appreciated from outside of its asserted truths - which, for Duras, was never of the same order as telling something as banal as the story of one's life. (DURAS, 1982; 1986; 1995.)

Instances of non-intentional omission stand out as points of appreciation in the deconstructions operated by Derrida. But intentional omissions reserve something fundamental to the non-said that could deny the economy at work in the formation of a concept like phallogocentrism.

In the aforementioned conference, Spurs, given at the Cerisy-LaSalle colloquium on Nietzsche in 1972, Derrida dealt with " woman » and phallogocentrism through an anti-essentialist perspective. In the citations to follow, I reproduce the English-language translation, with the following caveat. Derrida redefines woman through a not quite veiled string of sexual innuendo that seems to have been deliberately played down by the translator, Barbara Harlow, who did not provide a translator's forward justifying her choices. The key conceptual string here is écarter-s'écarterécart, meaning both averting as in keeping distant from, as Harlow translates the first term, but s'écarter also means opening one thighs. Indeed, Derrida plays off against the unfathomable depths of a woman's inner sexual reaches against Nietzsche's abyss, thus deconstructing the latter's ventures through the metaphoricity of the labyrinth into unrequited sexual desire. As Derrida writes:

There is no such thing as the essence of woman because woman averts (écarte), she is averted by herself (s'écarte elle-même). Out of the depths, endless and unfathomable, he engulfs (engloutit) and distorts (envoile) all vestige of essentiality, of identity, of property. And the philosophical discourse, blinded, founders on these shoals and is hurled down these depthless depths to its ruin. There is no such thing as the truth of woman, but it is because of that abyssal divergence (écart) of the truth, because that untruth (non-vérité) is "truth". Woman is one name (un nom) for that untruth (non-vérité) of truth.” (Derrida, 1979, p. 51. Translation modified.) 
Further setting up this deconstruction of Nietzsche's anti-feminist delirium, Derrida transposes the expression "history of an error" from Twilight of the Idols, in a context that was already considerably polysemantic. Through this concept of history, the thread of the conference, the signifier "spurs" does not stop being dislocated. It is spliced as such into a series of multilinguistic terms, among which the following are found: from the phallic éperons in French, to the capacity to tear and penetrate (from spur and spurn in English), all the way to indication, trace and mark from Spur in German. From style to subject, to woman and phallogocentrism, to error and dissimulation, Derrida takes on, as in few places in his work, a dense albeit malevolent strategy against truth and its possible retentions.

In the course of the conference, Derrida aimed at intertwining femininity and style, above all artistic style. The latter would be the practice to best rebut castration and its threat, making the body available as such to the place of the writing of self, and therefore breaking with phallogocentrism. (Derrida, 1979, p. 65). He begins this articulation, this deconstruction, of Nietzsche by citing a host of the latter's most outrageous, polemical or outright sexist assertions on Frau and Weib, woman-as-wife and woman-as-female-idea. The strategy presented by Derrida is to gloze with irony these statements, emphasizing how woman is "model of truth [because] she is able to display the gifts of her seductive power, which rules over dogmatism, and disorients and routs those credulous men, the philosophers" (Derrida, 1979, p. 66). Still, the two writers seem to converge on the orthodox point in the French intellectual milieu of post-structuralism that "the entire female operation gives space (s'espace) to this apparent contradiction.” (Derrida, 1979, p. 66. Translation adjusted to bring forward the aforementioned string of sexual innuendo.) In fact, this is a question of a double distance with truth and with logophonocentrism around s'espacer). Derrida seeks to shift the "gap" (écart) in contradiction to the truth from its meaning of dissimulation and apodicticity, toward an opening to aporia by elevated the Two in an original sense of sexual contact. What interests us is when and where the irony actually ends?

Let us recall that in this beginning of the nineteen-seventies, the dilemma involved in how to define "woman" (La femme) was once again intensively undertaken by diverse perspectives in the Parisian setting. At 
that time, woman would again become a new concept. That the treatment of this question was profoundly worked on by Simone de Beauvoir in the nineteen-forties makes the utter absence of citations, references and arguably even veiled references to her work in Derrida's philosophy a real problem.

One of the effects of this speaking silence for posterity, and perhaps for Derrida's thought in Brazil, is that The Second Sex still remains marginalized in most course outlines and bibliographies in philosophy curricula. The upshot is that the book is held in the odd state between that of an accepted masterpiece whereas not requiring to be read as such. For a country now infamous internationally for giving sway to a rabidly antifeminist reaction centered on stamping out teaching of the misguidedly termed "ideology of gender" (ideologia do gênero), this simply shows how philosophy professors have failed in the task to channel women's liberation movements in thought as a fundamental duty of ontology, ethics and rights.

As such, the last thing we seek is to interpret what would be the intention of the author/narrator/conceptual character of Jacques Derrida involved in this omission. Nonetheless, it seems to me that this marginalization of Beauvoir's book is intentional and desired for some reasons that may have been justified at the time, but for other reasons they now stand out as utterly unacceptable. These conflicting reasons may be seen to justify the considerable prudence with which Derrida was received by North-American feminist thought in the late nineties especially, as it is possible to read in two anthologies edited by Feder, Rawhissan and Zahir, Derrida and Feminism and by Nancy Holland's Feminist Interpretations of Derrida, both published at the end of the century.

By staking out these considerations, I am interested in encountering positions among Brazilian scholars as well on how to deal with this relation and check to see whether it is possible to classify it according to Derrida's own concept of metaphoricity as implying a nonrecognized debt. I have found few reactions. The main one comes from Carla Rodrigues, from the Federal University of Rio de Janeiro (UFRJ), a leading scholar of Derrida's work and its impact upon feminist theorists, such as Judith Butler. In Derrida's works on the question of "woman" and sexual difference, published in Geschlecht, Veils, The Post Card, On Touching in addition to Spurs, such statements seem to evoke activities 
congruent with the objectives and needs of the feminist critique of phallocracy and of the philosophy supporting it. (RODRIGUES, 2012) In diverse analyses, Rodrigues subscribes to the thesis according to which a presence of the Beauvoirian oeuvre stretches silently, perhaps hauntingly, over Derrida. According to her,

I do not believe it is possible to establish that Beauvoir directly influenced the thought of the Franco-Algerian philosopher Jacques Derrida due to all that is different between them. Derrida was a critic of Sartre's reading of Heidegger, a critic of the existentialism and humanism of which Beauvoir was fully a part, and an heir to Levinas' ethical propositions. As such, while it is not my intention to establish any type of link between Beauvoir and Derrida, I aim to conclude by pointing to how the thought of this philosopher radicalizes the critiques of modernity that were being drawn up in the 1950 and 6os. (Rodrigues, 2012, p. 245)

Allow me to observe that what Rodrigues does not take into consideration is how the absence of Simone de Beauvoir's name in Derrida's work may be problematized in continuity with the accusative concept of phallogocentrism. From this perspective, putting the thought of otherness under his leadership would risk representing the French context of second-wave feminism in the transitional epoch of the early 1970 s as if it had resulted above all from the work of philosophers, and not from the radical political praxes of, say, the Mouvement pour la libération des femmes (MLF) and the experimental art of l'écriture féminine led by the Éditions Des femmes publishing house.

If this point were granted to me, then I can move on and make two observations of a conceptual nature.

The first has to do with the categorical set that is transcendence in dialectical reasoning, and the division of the sexuated subject, or sexual difference in the field of the logic of otherness. This second set was treated masterfully by Derrida in Geschlecht I (Sexual difference, ontological difference).${ }^{9}$ If the definition of woman requires a barring of the figure of the Other, the condition that appears both in claims for equality and in the demand for a specific definitional logic, then Beauvoir undoubtedly carried this out. If by Derrida's silence regarding her, Beauvoir's position must be understood as limited to essentialism, then Derrida becomes

${ }^{9}$ DERRIDA, J. “Geschlecht: sexual difference, ontological difference”, Research in Phenomenology. Vol. 13 (1983). 
contradictory, since Beauvoir takes the Heideggerian "anticipatory decision" to its instantiated conclusion in the authentic form of existence in which difference is irreducible, for it is sexuating difference.

As such, I have to express my agreement with Maria Luisa Femenias, who takes a stand against Judith Butler's critique of Beauvoir. Femenias argues that the epistemological positions developed in The Second Sex are more in continuity with Merleau-Ponty's body-based phenomenology than Sartre's obsessions with consciousness. Femenias' analyses seem to silently consider that Butler's position is similar to what Derrida inferred, namely that Beauvoir, despite her feminist pedigree is all in all an essentialist thinker - though this we shall never know since he has stated nothing about her.

I should like to add that I am ready to accept that the postpatriarchal temporality foreseen by Beauvoir in the concluding pages of $L e$ Deuxième Sex are a conciliation to heteronormativity (Beauvoir, pp. 685687 , foremost). Still, when rereading these pages, the impression one gets is that of caution, much more than a permanent position, let alone of the affirmation of an essentialist humanism applied to the body. It is necessary to listen to Beauvoir when she writes: "In girls as in boys, the body is first of all the radiation of a subjectivity, the instrument that makes possible the comprehension of the world: it is through the eyes, the hands, that children apprehend the universe, and not through the sexual parts." ${ }^{10}$ Despite writing "boy" and "girl", in "irradiating subjectivity" there is nothing if not transformational experience, indeed a performative one.

Neither naturalist nor essentialist, Beauvoir's terminology closely follows Heidegger's - which becomes Derrida's own when he returns to emphasize the "dispersive" aspect (Zerstreuung) of Dasein in Geschlecht which justifies the indeterminacy of sexual division in the context of the improper existence within facticity. According to Derrida, "It is an original structure of Dasein that affects [the 'metaphysical' neutrality of man], with the body, and thus sexual difference, of multiplicity and disconnection, these two meanings remaining distinct, although reunited, in the analysis of dissemination (Zerstreutheit or Zerstreuung)." ${ }^{11}$ What I

\footnotetext{
${ }^{10}$ BEAUVOIR, S. de. The Second Sex. p. 273. (,Le Deuxième sexe, livre 2. p. 8. : « Chez les filles et les garçons, le corps est d'abord le rayonnement d'une subjectivité, l'instrument qui effectue la compréhension du monde : c'est à travers les yeux, les mains, non par les parties sexuelles qu'ils appréhendent l'univers. »)
}

${ }^{11}$ DERRIDA, 1987, p. 161. 
would add furthermore is the suggestion that sexual division is not reduced to neutrality by the concept of Dasein, since Dasein, understood in the post-humanist framework, is not even "man". A juxtaposition with Butler on this point makes it even more complex to eliminate Beauvoir's conceptual strategy: "The effect of gender is produced through the stylization of the body and, hence, must be understood as the mundane way in which bodily gestures, movements, and styles of various kinds constitute the illusion of an abiding gendered self." (BUTLER, 2002, P. 191.) Beauvoir was already pointing to a normative dimension of the human being's biology.

The second observation refers to statement made by Catherine Malabou on anti-essentialism, the force of which weaves Derrida's work and is recognized as such by her. The logical option Derrida presents in Spurs by means of his so-called "deconstructivist interpretation" of style in Nietzsche, as juxtaposed with woman, "which will be the subject of his talk", aims at a deconstruction of the modalities of phenomenal appearance as worked out by phenomenology and hermeneutics. The logos of the veil and veiling is thus deconstructively led to engage with the concept of simulacrum. This latter concept was introduced by Gilles Deleuze and applied to substitute the notion of creation or self-creation in the span of differential concepts. (Deleuze, 1969)

Malabou is opposed to the radical implications of this antiessentialist position (Vahanian, 2008; reiterated in Malabou, 2014, Subversions). She argues from the diffractionary metaphoricity of the selftouching lips as conceptualized by Luce Irigaray (1985) in her own bid to give value to a post-essentialist perspective. Raising an objection against the dissimulatory aspect of woman as conceived in psychoanalytic discourse, which would make the performing artist into the quintessential figure of woman, Malabou takes exception to a tendency she sees as occurring in the aftermath of the positions first espoused by Derrida in Spurs. If Malabou does not return to Beauvoir in detail, she does reintegrate the Hegelian dialectical framework intrinsic to the former's methodology of existentialist morality. Malabou's thesis derives from her reading of Being in Hegel, defined as "to be, is to be negated". In the Second Sex, the name of this is the "generic", the term by which the second part of the work ends in an appeal to Marx and Engels that resonates among different authors and writers, and among men, or at least it ought to. What 
lamentably remains is the deceptive and dissimulational deviation that Virginie Despentes and Paul B. Preciado more recently lament in the deservedly aggressive tonality of King Kong Théorie and Counter-sexual Manifesto, respectively. Where Despentes laments the fact that "What is the autonomy of which men are so afraid that they keep being quiet and inventing nothing? Producing no new inventive discourse, critique about their own condition? When will men's liberation occur?" (Despentes, 2009, p.119). Preciado works through an inversion of the phallic as a divisional imposition of law to a sexual community based on the commons of anal sexuality, and the materialization of plasticity and the simulacrum in the dildo as a counter-cybernetic access to the virtual. From this basis, anti-essentialism irradiates into the new transcendental potential embedded in the term performance.

These instances of subversion set limits to Derrida's phallo-logophono-centrism. Despentes' once anti-academic conceptualization of rape culture meets up perhaps more directly with Jane Gallop's skepticism regarding Derrida than Preciado's. Gallop was the first thinker to introduce second wave French feminist researchers to the literature on psychoanalysis, philosophy and epistemology in the English-speaking world. In The Daughter's Seduction, Gallop considers that with his critique of Lacan for phallocentrism, "Derrida is approaching the proper epithet, but misfiring by virtue of adherence to polite, discursive, philosophical terms that fall short of the scandal in Lacan's position. It is too eloquent, too comfortable, too complicitous with philosophical mastery, simply to claim that Lacan is phallocentric." ${ }^{12}$ " In her estimation, what Lacan's conceptual behavior demonstrates is something akin to "phalloexcentrism".

The destiny of the concept of phallogocentrism is thus not specifically feminist, nor is the research on granting to the concept of woman an epistemological coherence from the categories of philosophy. Derrida would go on to join the term meat/flesh (chair) to the expression,

\footnotetext{
${ }^{12}$ GALLOP, J. Feminism and Psychoanalysis: The Daughter's Seduction. p. 36. The author goes on to add: "Lacan's practice, in so far as it is traversed by resistances to metaphysical discourse and by irruptions against Oedipal paternalism, is only accessible in an earthier, less categorial discourse, attuned to the register of aggression and desire. Not simply a philosopher, but, artfully, a performer, he is no

mere father figure out to purvey the truth of his authority; he also comes out seeking his pleasure in a relation that the phallocentric universe does not circumscribe. To designate Lacan at his most stimulating and foreceful is to call him something more than just phallocentric. He is also phallo-eccentric. Or, in more pointed language, he is a prick."
} 
according to Peteers (2010), but this is of little importance. Meat/flesh is not the body, even were it through deconstruction of flesh and not merely carnivorous consumption, as initiated by Merleau-Ponty and further developed by Irigaray. The latter aspects of phenomenological research may very well have been preparatory exercises for a philosophical critique of the humanist, neutral body, but it does not refute the thesis according to which the body is absent in ontology - as may possibility be life that is neither zoe nor bio, but plasticity.

This position merely meets up with claims made in Englishlanguage feminist scholarship two decades ago. Gayatri Spivak, for example, had already voiced reluctance regarding the implications of Derrida's critique for feminism. According to her, "however, and this is key, deconstruction is not convincing as that alternative discourse itself; 'as a feminist discourse"' (Spivak 1997: 6o). Spivak rules out Derrida's contribution as implying a feminist stance even implicitly. Deconstruction per se does not imply feminism, nor it is a project for a future feminism, be it a messianic feminism to come... "It is caught on the other side of sexual difference" (Spivak 1997: 6o). ${ }^{13}$ Were to search through various statements made about the importance of Beauvoir book from the perspective of the witness, that is, from those women whose lives were profoundly changed by The Second Sex, it is the relationship to the female body that is most often evoked. Laure Adler, Marguerite Duras' biographer, is one who assert that Simone de Beauvoir's texts

have inhabited our bodies and made them different to ourselves as well as awoken our awareness. Moral conscience and consciousness as such emerge through the event of the body. I refuse to question this "ourselves", since the destination, the "envoy", is the body as problem, question and event. ${ }^{14}$

Adler, who wrote the Femina-awarded biography of Marguerite Duras, and once produced a five-part interview with Derrida for Radio France Culture, adds: "Beauvoir has given us so much we ourselves don't

\footnotetext{
${ }^{13}$ IRWIN, Jones, Derrida and the Writing of the Body, p. 124.

${ }^{14}$ ADLER, L. "Trop de Simone tue Beauvoir », Les Temps Modernes, No. 647-648, 2008, p. 143.
} 
know how her texts continue to work within us, once again, I insist, inside of us, body and soul all mixed together." ${ }^{15}$

Indeed, what Beauvoir thought through was a structural relation evoking Platonism not as much through mimesis than methexis, not by imitation but by participation, transcendence. Leaving the immanence of the "en-soi" that shuts the Other out from the space of subjectivation makes intelligible a structural dimension split from binarism, in which the Other renovates the position and grammar of the signifier in a postDerridian scope, since it is part of the event. According to methexis, by which the formal and ontological structure of the simulacrum is derived in (Derrida, 1979), as well as in (Deleuze, 1969), it is determined not by representation but by a relational and differential structuring, according to which the Other is neither substance, nor limit, but temporal figuration, performance. Its essence, insofar as there is one, is not identity, but a space in which movement is multiform, inconstant, post-dialectical and indeterminate in its relation with the social. Through her "existentialist morality of ambiguity", Beauvoir appears to have already gone beyond post-structuralism for much the same reason that post-structuralism seems to have already been superseded by structuralism.

This assessment appears to invite a feminist-epistemological reflection on the limits of philosophical discourse and the latter's inner dynamic to expel otherness from within its bounds. Quite to the contrary of the Derrida-Levinas tandem, the Other would as much be the target of the subject's predation, as it would of its perpetual deferral. Philosophy does not need to assassinate the Other, as its power rests upon a reason that feels unthreatened by it, let alone demands to define woman's singularity.

This is why Simone de Beauvoir's ambiguity is so precious regarding the figure of Other in the introductory passages of the first volume of The Second Sex. The Other cannot be either an alternate position of complete truth, nor its emptying out. Her economy partially goes through truth, but it does so mainly through taking on the biological, psychoanalytic and historical set of lies about women. Her approach to setting the record straight is done so less in the terms of an essence than as constitutive appearance Capturing the lies about woman's biological, 
psychic and intellectual inferiority is her primary strategy in Book I, subtitled "The Facts and Myths". While the first occurrence of the word "lie" in The Second Sex is expressed as passive destiny ("this is woman's first lie (mensonge), first treason: namely, that of life itself-life, which though clothed in the most attractive forms, is always infested by the ferments of age and death" ${ }^{16}$ ), the dynamic dimension of the deceptive, emancipatory, lie is best evoked when she writes: "only through deceit (mensonge) and adultery can she prove that she is nobody's chattel and give the lie (dément) to the pretentions of the male." ${ }^{17}$ In the end, and decades before Spurs, it is by deceit, indeed dissimulation, that "woman" would be emancipated from men's possession-as well as from the philosopher's.

At the time of Spurs, the history that fascinated Derrida was merely that of an error. Unless I am mistaken, the history of the lie would only take shape in the 1990s, that is, some twenty years later. Although, Deleuze's field is limited to the political lie, at a level of international relations between nation-states, the definition of woman is nothing but political. At the beginning of the 1970s, Derrida had other more pressing concerns to deconstruct, namely that of Jacques Lacan's structural psychoanalysis. The concept of phallogocentrism was coined to deal with Lacan, even if, since the beginning of the 1970s, Lacan was already testing the formulae of sexuation, in which, similarly to Derrida, he would reach the limits of Western rational discourse by configurating the logical operation of subtraction as a rift with the phallic order.

The upshot of Lacan's own argument was the the proposition/conclusion: "la femme n'existe pas" ("woman does not exist"). ${ }^{18}$ One can rightly ask: did Lacan only briefly explore the consequences of this claim? Plausibly, so. In this regard, I agree with Adrian Johnson who sees shortcomings more in the scholarship regarding the complexity of the claim than of Lacan's different interpretations of it. ${ }^{19}$ That said, did Lacan excessively play and provoke with this assertion? To read his texts from the time around which Seminar XX was given, there is

\footnotetext{
${ }^{16}$ BEAUVOIR, 1953, Book I, p. 178.

${ }^{17}$ Both of these cases occur in Book I, Chapter I of « Myths ». Ibid., p. 203.

${ }^{18}$ LACAN, J. Seminar XX, p.

${ }^{19}$ JOHNSTON, A. "Non-Existence and Sexual Identity: Some Brief Remarks on Meinong and Lacan," Lacanian Ink: The Symptom, no. 3, Fall/Winter, 2002. <http://www.lacan.com/ nonexistf.htm.>
} 
little doubt. Is the crossed out concept of "The Woman" (La Femme) transcendent or transgressive, in the way Beauvoir argued, or indeed performative? Today, I believe that it was indeed, even the topological density of this differential space, as in other cases of the logical economy and dynamics of difference, required time and experiments to be distanced from the dialectical figure of the Other.

It was against this dialectical enclosure that Beauvoir already manifested her point by considering the figure of "absolute evil" to be the foreclosure of woman from occupying the space of the subject. This is the only such space that by definition agrees with what she named "existentialist morality". ${ }^{20}$ According to this methodological and normative commitment, transcendence would materialize a radical transformation, including from the subject-object complex, as Beauvoir defended by means of Marx in the concluding passages of the work. In the existentialist perspective, desiring the other is akin to desiring the object, the "en-soi", or indeed to be the object, which is why this act is seen as a case of bad faith. But the existentialist project is akin to desiring greater degrees of subjectivity! Moreover, according to Freud, the desire of the object is enabled by accepting castration, the gesture of which triggers sexual differentiation only within the strict parameters of heteronormativity-which Beauvoir also shows to be theoretically and morally decrepit.

As for dissimulation more broadly conceived, it was Marguerite Duras who suggested differentiated perspectives to emphasize how simulating also ends in violence, save for cases such as that told in the novel about Lola V. Stein (Duras, 1964). In this narrative of betrayal, psychotic breakdown and subjective reconstruction by the voyeuristic fetishism of viewing a beloved couple having sex, Duras first articulates the sex that is not one, the sex that takes shape by lips in contact in the act. Whether Lol witnesses penetration is not made clear by the narrator, whose voice she assumes in the pivotal moment of coitus. Yet it is bodily contact that ensures the constitutive force of the lips and of the two. It was Lacan who would commemorate in the conclusive sentences of his essay on Le Ravissement de Lol V. Stein in 1964, how the loss of the object(a) 
was symbolized by the reduction of Lola to Lol, as if the loss of the aleph led her to exit from the symbolic order by means of the "taciturn nuptials of empty life with the indescribable object". (Lacan, 2001).

The question then is to attempt to understand whether the condition by which phallocentrism is named, inasmuch as it articulated in an inter-dimensional and therefore differential torsion does not shut out the discursive space to a deconstruction that would deconstruct Derrida himself. Would this not be the manifestation of anguish, or worse, of an improper (uneigentlich) fear, to be seen as bound to the figure of the mother philosopher, whereby Derrida's a singular identity would be deleted in becoming merely a son, as sustained by the symbolic order, despite the force by which his anti-essentialism is asserted? Or, indeed, something even more primordial, a dependence on the mother for protection and reinforcement, to whom the son's body as future father would also be indebted as regards it untouchable limits and rim?

Derrida would not have taken objection to be treated as an antiphilosopher. It is possible to occupy this perspective and go further, go the "distance", s'écarter bodily in thought as in philosophy, to cite the metaphoric string again of Spurs. It is not then by chance that the text creates its own limits, its limits as philosophy, the exemplary text of the antiphilosophical style with which so many commitments in French thought experimented at the time of Spurs. The sad fact may very well be that there is no other Derridian concept that resists more to indetermination than phallogophonocentrism. Its claims are specific. But we can also agree with Rosi Braidotti when she refers with disdain to the Derridian take on woman as "negative feminism"21. This would be a type of feminism with no content. As such, the term phallogocentrism would be a conceptual creation that places limits onto indeterminacy itself.

Nonetheless, it is necessary to take on these omissions by history and specially by the notions of the history of an error, and by the title and content of a conference given by Derrida first at the New School for Social Research in 1993, "History of the lie: prolegomena". ${ }^{22}$ In other words,

\footnotetext{
${ }^{21}$ BRAIDOTTI, 1991.

${ }^{22}$ According to Martin Jay (2009, p. 235), "In 1993, Jacques Derrida was invited to participate in a lecture series at the New School dedicated to the memory of Hannah Arendt, who was closely associated with the school during much of her American exile. As far as I know, the talk that resulted was the only sustained attempt by Derrida to address and draw on Arendt's work. Entitled "History of the Lie: Prolegomena," it was published in several places, most recently in the collection edited by Peggy Kamuf, Without Alibi. »
} 
would Beauvoir's absence in Derrida's entire oeuvre be the history of an error or that of a lie? The Second Sex may be considered, at least in part, as the history of an error as related to the representation of woman as inferior to man. It also works as the history of a lie, when dealing with the set of justifications fostering the assertion and sustainability of such a claim. Returning to the question: would these cases of absence be the result of an error or lie? According to what temporality must this omission be deal?

The history of the lie, as Derrida claims, is the history of afabulation, the history of the false witness. (Derrida, 2003) By which the allegation over the omission of a key female thinker and of an equally monumental writer in the articulation of phallogocentrism, apart from performatively implicating Derrida, implicates myself circumstantially. That I, or myself, in this space of utterance that gives me legitimacy, that is, phallocracy, is an attempt to provide density to the indiscernible topos of a sexuated subject that is not one, can only pass through a first moment of negating philosophy by antiphilosophy. Yet Beauvoir did not require antiphilosophy to undertake her own history of the lie, namely that of the essential inferiority of woman such as represented, asserted, demonstrated, justified, reproduced, repeated and concluded in the hegemonic thought of patriarchal society. Not even in this regard does Derrida cite Beauvoir.

To agitate our curiosity a little more, I put forward four hypotheses toward speculative projects on why this might have happened.

1. Derrida's ambition. Derrida did not return to any of the existential phenomenologists after publishing his definitive contributions on Husserl in the 1960s. Still, Beauvoir was not a typical existentialist, and long before Derrida, she opened a dispute with Emmanuel Levinas in the first pages of Le Deuxième sex. We shall not enter into the scholarship that has speculated about the impact her critique had on Levinas's work. My point is simply that Derrida does not mention her even in regard to Levinas. Then again, Levinas also muted any reference to her.

2. Derrida will be remembered in most studies on twentieth-century French philosophy as having initiated the discussion with Levinas within philosophy, thus preparing the ground for the latter's ascension to the philosophical pantheon in the late 1980 s. Indeed, judging by a work as respected as Vincent Descombes's Modern French Philosophy (Le Même et l'autre), Levinas was not even part of the philosophical scenario in France in the late seventies - despite 
having been the one to first import phenomenology to the country through his translation of Husserl's Cartesian Meditations and by his discussion of the existential analytic in En Découvrant l'existence avec Husserl et Heidegger, en 1949 .

3. All of this said, it is plain that Derrida did not recognize any woman to be his philosophical equal, even though he worked with many women and receiving much acclaim from various important women scholars through his personal, professional and conceptual disposition to think "woman". Witnesses such as his wife, Marguerite Derrida, related to Benoit Peeters how "I always thought that it was mainly through his capacity for listening that Jacques could seduce women.” (Peeters, 2010, p. 422.) Peteers rightly adds, "This quality, rare in a man, is even rarer for a thinker of Derrida's credentials, and would have impressed many of the women he frequented." (Ibid.) Peeters cites Derrida1s friend, Marie-Claire Boons, who is happy to say as much: "I found in him an absolute ability to listen that I've never come across in anyone else. An abstention from all moral judgement. In every situation, he wanted to go where life was." (Ibid.) However, this recognition perhaps hid the shortcomings in the negative critique of phallogocentrism, for Derrida did not contemplate the epistemological and ontological dynamic involved in defining woman, namely by undoing man. Despite his anti-essentialism, he chose to remain mainly within the order of man-and perpetuate it by deferral.

4. Finally, we come to the letters S.A. Were we interested in puns, we could suggest a return to Derrida's infamous dispute with John Searle in Limited Inc. over the adequate interpretation and use of the performative utterance. After all, S.A. is the French analogue to "incorporated", meaning "société anonyme" (anonymous firm, partnership). They also oddly evoke the initials of Sylviane Agacinski, Derrida's estranged partner and critical witness to Beauvoir's adverse position regarding maternity. Agacinski did not buy into Beauvoir's denigration of the ostentatiousness of female beauty. A friend of Catherine Malabou prior to her own friendship with Derrida, in 1998, Agacinski would write in favor of a naturalist essentialism on woman - or women. It is true that since 1984, Agacinski did not talk anymore with Derrida. In the 1970s, one ought to observe, she was critical about on Beauvoir on various issues, especially at the time she was a key player in the development of Derrida's own feminist turn. ${ }^{23}$ In homage

23 « On naît fille ou garçon, on devient femme ou homme. La différence sexuelle est une donnée naturelle que les sociétés interprètent diversement ", writes Sylviane Agacinski in Politique des sexes, Le Seuil, 1998, p. 30. Ms. Agacinski, it must said, brings new depth to the question of anonymity and the secret. The biographer, Benoit Peeters, relates how « The borders between public and private life are one of the most delicate questions which a biographer encounters. And the long love affair between Derrida and Sylviane Agacinski that started in 1972 is one of the major difficulties the present biographer has had to face. Agacinski was not willing to present her own account, and the immense correspondence that she exchanged with Derrida will apparently be inaccessible for a long time." In the footnote to this statement, Peeters writes "according to acquaintances, nearly a thousand letters from Derrida have been preserved by Agacinski. In the pages of the present work, the reader will have had a chance to appreciate how 
854 | Veritas | Porto Alegre, v. 62, n. 3, set.-dez. 2017, p. 835-859

to her, I believe the silent, anonymous partnership she once represented for Derrida ought to be seen to suggest a very special, if only personal, testimony to the omission of Simone de Beauvoir.

These are hypotheses, as they are also indicators, if not an indictment, for what is at stake is the perpetuation of the history of an error whose result is the history of women themselves. In such a history specific to women, even in the figure of the thinker of phallogocentrism, we remain under the protection, guard and enclosures of the great European man, no matter where he was born. In this regard, I should like to wrench out a stronger thesis, according to which the critique of phallogocentrism is not conducted by a gesture of good will for it would reinforce the primary fundamental prohibition as of yet unassumed. Neither the prohibition of incest (as espoused by Freud and Levy-Strauss), nor homosexuality as such (defended by Butler), the primary prohibition of Western thought is that of the penetration of a certain body. Dissimulated by the critique of phallogocentrism, this body can only be that of the father.

How would Derrida react to this thesis? Fortunately, there exists a late text, On Touching, in which by the penetration of the paternal body points to an option for greater inclusion in the philosophical discussion that would not depend on the Other after all, but the heterosexual male self split apart by the thrust of the touch. Fittingly written by two, by "n1" as Deleuze and Guattari could have formulated, Derrida and Jean-Luc Nancy take phenomenological description into new sensory areas for heteronormativity, as if to articulate a new proposal, heteromultiplicity. I quote this fundamental, work-saving, passage at length:

What, then, is a treatise of touch that says nothing about this: "Who touches whom? And how?"; "Who strikes whom? Who strokes whom? And why? And how?" Let us insist again that various causes or qualities do not come and modify or modalize one single, selfsame, presupposed generality of what we conveniently term the "caress" and the "blow". There again, they constitute a multiplicity without the horizon of a totalizable unity. For, let us not hide this from ourselves, by this stroke, and with a caress - a caress may be a blow and vice versa-it comes down to the conceptual condition of concepts. And let us not exclude either that

talented a letter writer Derrida was; so one may indulge in dreaming of these letters and hoping that they will be published one day, even if far in the future." (Peeters, 2010, p. 44 and footnote). 
certain experiences of touching (of "who touches whom") do not simply pertain to blows and caresses. What about a kiss? Is it one caress among many? What about a kiss on the mouth? What about a biting kiss, as well as everything that can then be exchanged between lips, tongues, and teeth? Are blows wanting there? Are they absent in coitus, in all the penetrations or acts of homosexual or heterosexual sodomy? Is a "caress," more so than a "blow," enough of a concept to say something of this experience of "touching" of which Aristotle, followed by all those who came after him in the great traditional philosophy of touch, hardly breathed a word? ${ }^{24}$

In other words and according to another metaphoricity, Derrida and Nancy may have reached the rim of heteronormativity after all, by situating the touch as the spur of an original forgotten penetration of the father's body, brutally repressed by cultural castration and the phallus, professedly to defend the foundation and force of modern Man.

\section{Concluding remarks}

Indeed, women liked and evidently loved Jacques Derrida. Yet through the concept of phallogocentrism, Derrida seems to have done more to be loved than withdraw from the heteronormative relational space by which "woman" needs to be carved into man's body as intrusion and transformation. For only then does theory and the world respond to the question of woman, sexual difference and inversion of places and pleasures. In that moment, shades of a new world may arise, from the rim of Derrida's secret and the crypt, toward other topologies unfolding from within the castrating patriarch wherein the Two is truly lived as the numeral of sex.

\section{References}

ADLER, Laure. “Trop de Simone tue Beauvoir », Les Temps Modernes, No. 647-648, 2008, pp. $143-145$.

BEAUVOIR, Simone de. The Second Sex. Translated and edited by H.M. Parshley. London: Jonathan Cape, 1953. (1 volume) [ Le deuxième sexe. Paris: Gallimard, 1949. Livre 1: Les faits et les mythes. Livre II: L'expérience vécue.]

${ }^{24}$ DERRIDA, J. and J.-L. NANCY, 2005, p. 69. 
856 | Veritas | Porto Alegre, v. 62, n. 3, set.-dez. 2017, p. 835-859

BRAIDOTTI, R. 1991. Patterns of Dissonance: Study of Women and Contemporary Philosophy. London, Polity Press.

BUTLER, J. Gender Trouble: Feminism and the Subversion of Identity. New York: Routledge, 1990.

BUTLER, J. Performative Acts and Gender Constitution. In CASE, S.-E. (ed.).

Performing Feminism: Critical Theory and Theatre. Baltimore: John Hopkins, 1990.

CIXOUS, Hélène. 'Interview', in V. Conley, V. Hélène Cixous: Writing the Feminine. Lincoln, University of Nebraska Press, 1991.

CIXOUS, Hélène. The Hélène Cixous Reader. Edited by Susan Sellars. London,Routledge, 1994.

CIXOUS, Hélène. Portrait de Jacques Derrida en jeune saint juif. Paris: Éditions Galilée, 2004 .

CIXOUS, Hélène. Portrait of Jacques Derrida as a Young Jewish Saint. New York, Columbia University Press, 2005.

CIXOUS, Hélène. Insister of Jacques Derrida. Edinburgh, Edinburgh University Press, 2007.

CIXOUS, Hélène and Jacques DERRIDA, Veils. Translated by G. Bennington. Drawings by E. Pignon-Ernest. Stanford, California: Stanford University Press, 2001 [1998].

CONLEY, V. Hélène Cixous: Writing the Feminine. Lincoln, University of Nebraska Press, 1991.

CORNELL, D. 1997. 'Where Love Begins: Sexual Difference and the Limits of the Masculine Symbolic', in Derrida and Feminism: Recasting the Question of Woman. Edited by E.K. Feder, M.C. Rawlinson and E. Zakin. New York, Routledge, 161-207.

DELEUZE, Gilles. Logiques du sens. Paris: Éditions du Minuit, 1069.

DELY, Carole, "Jacques Derrida: The Perchance of a Coming of the Otherwoman. (The Deconstruction of 'Phallogocentrism' from Duel to Duo). Sens public. Published on line: 2007/10. <http://www.sens-public.org/article.php3?id article=312>, 2007/10, pp. 1-15.

DERRIDA, Jacques. Marges. De la philosophie. Paris: Éditions du Minuit, 1972.

DERRIDA, Jacques, Spurs: Nietzsche's Styles. Éperons. Les Styles de Nietzsche. Introduction by Stefano Agosti. English Translation by Barbara Harlow. Drawings by François Loubrieu. Chicago, Ill.: The University of Chicago Press, 1979 [1978].

DERRIDA, Jacques, "Différence sexuelle, différence ontologique" (Geschlecht I) in Heidegger et la question. Paris: Flammarion, 1990, pp. 145-172. 
DERRIDA, Jacques, "History of the Lie: Prolegomena”, Without Alibi, ed. and trans. Peggy Kamuf, Stanford, 2002, pp. 28-70. (Earlier versions appeared in Graduate Faculty Philosophy Journal, IX, 2 and XX, 1 and Futures of Jacques Derrida, ed., Richard Rand (Stanford, 2001).)

DERRIDA, Jacques and NANCY, Jean-Luc. On Touching. Translated by Christine Irizarry. New York: Stanford University Press, 2005 [2000].

DESCOMBES, Vincent. Modern French Philosophy, Cambridge University Press, 1980.

DESPENTES, Virginie. King Kong Theory. Translated by Stephanie Benson. New York: Serpent's Tail, 2009.

Derrida and Feminism: Recasting the Question of Woman. Edited by E.K. FEDER, M.C. RAWLINSON and E. ZAKIN. New York, Routledge,1997.

DURAS, Marguerite, Le Ravissement de Lol V. Stein. Paris : Gallimard, 1964.

DURAS, Marguerite, L’Amant. Paris: Éditions du Minuit, 1982.

DURAS, Marguerite, Les Yeux bleus, les cheveux noirs. Paris : Éditions du Minuit, 1986.

DURAS, Marguerite, La vie matérielle. Paris : P.O.L., 1987.

DURAS, Marguerite, Écrire. Paris : Gallimard, 1995.

FEMINIAS, María Luisa. “A crítica de Judith Butler a Simone de Beauvoir”, Sapere Aude Belo Horizonte, Tradução e Revisão de Antônio Aurélio de Oliveira Costa, Jacyntho Lins Brandão e Valéria De Marco Fonseca v.3 - n.6, p.310-339 - $2^{\circ}$ sem. 2012, pp. 310-339.

Feminist Interpretations of Jacques Derrida. Edited by N. Holland. Pennsylvania, Pennsylvania University Press, 1997.

FLORES PEÑA, G. "Interview with Catherine Malabou," Figure/Ground. May 12, 2016. < http://http://figureground.org/interview-with-catherine-malabou// >.

GALLOP, Jane, The Daughter's Seduction: Feminism and Psychoanalysis. New York: Cornell University Press, 1982.

GALLOP, Jane, Women" in Spurs and Nineties Feminism', in Derrida and Feminism: Recasting the Question of Woman. Edited by E.K. Feder, M.C. Rawlinson and E. Zakin. New York, Routledge, 7-21.

GROSZ, Elizabeth, "Derrida and Feminism: A Remembrance", in d iff e r e n c e s : A Journal of Feminist Cultural Studies16:3, 2005, pp. 88-95.

IRIGARAY, Luce, Speculum of the Other Woman. New York, Cornell University Press, 1985. 
858 | Veritas | Porto Alegre, v. 62, n. 3, set.-dez. 2017, p. 835-859

IRIGARAY, Luce, This Sex which is Not One. Translated by Catherine Porter. New York, Cornell University Press, 1985.

JAY, Martin. "Pseudology: Derrida on Arendt and Lying in Politics", Derrida and the Time of the Political. Pheng Cheah and Suzanne Guerlac (editors). New York: Duke University Press, 2009, pp. 235-254.

JOHNSTON, Adrian. "Non-Existence and Sexual Identity: Some Brief Remarks on Meinong and Lacan," Lacanian Ink: The Symptom, no. 3, Fall/Winter, 2002. http://www.lacan.com/ nonexistf.htm..

IRWIN, Jones, Derrida and the Writing of the Body. Surrey, UK: Ashgate, 2010.

LACAN, Jacques. Seminar XX New York: W.W. Norton \& Co, 1998.

LACAN, Jacques, Autres écrits. Paris: Éditions du Seuil, 2001.

PEETERS, Benoit. Derrida: a Biography. London: Wiley, 2010.

PRECIADO, Paul Beatrice. Manifesto contrasexual (Countersexual Manifesto) [Manifesto contrassexual. Práticas subversivas de identidade sexual, tradução de Maria Paula Gurgel Ribeiro. São Paulo: n-1 edições, 2014. 2002]

POWELL, Jason. Jacques Derrida: a Biography. London: Continuum, 2006.

RODRIGUES, Carla. Rastros do feminino: sobre ética e política em Derrida. Unpublished Ph.D. dissertation. Rio de Janeiro: 2010. Available at < https://www.maxwell.vrac.puc-rio.br/17394/17394_1.PDF>.

RODRIGUES, Carla, "Performance, gênero, linguagem e alteridade: J. Butler leitora de J. Derrida." Sexualidade, Saude e Sociedade (Rio J.) no.10 Rio de Janeiro Apr. 2012 http://dx.doi.org/10.159o/S1984-64872012000400007.

RODRIGUES, Carla, "Beauvoir com Sade: ética, ambiguidade e alteridade", in SapereAude- Belo Horizonte, v.3 - n.6, p.234-249 - 20 sem. 2012.

ROUDINESCO, Elisabeth. Philosophes dans la tourmente. Paris: Fayard, 2005.

SPIVAK, G.C. 1997. 'Displacement and the Discourse of Woman', in Feminist Interpretations of Jacques Derrida. Edited by N. Holland. Pennsylvania, Pennsylvania University Press, 40-65.

VAHANIAN, Noelle. "A Conversation with Catherine Malabou." Journal for Cultural and Religious Theory, vol. 9 no. 1 (Winter 2008): 1-13. 
N. R. Madarasz - The Forgetting of the Penetrable Body | 859

\section{FILMS AND RECORDED CONFERENCES}

DURAS, Marguerite, “ Marguerite Duras à propos du "Ravissement de Lol V.Stein" », Ina.fr. <http://www.ina.fr/video/Io4257861>15 avril 1964b, 13min 36s.

Jacques Derrida, by Kirby Dick and Amy Ziering (Zeitgeist Films, 2002).

MALABOU, Catherine. "Post-Gender Theory and the Feminine", at the 7 th Subversive festival: "Power and Freedom in the time of Control", 12/5/2014, Cinema Europa, Zagreb, Croatia. <https://www.youtube.com/watch?v=oMOlisKRO5M>.

\section{Endereço postal:}

Programa de Pós-graduação em Filosofia da PUCRS

Av. da Ipiranga, 6681, prédio 5 - Porto Alegre, RS, Brasil

Data de recebimento: $20-11-2017$

Data de aceite: 01-12-2017 